\title{
E-MODULE INNOVATION AS A LEARNING SOLUTION FOR CHEMISTRY COURSE DURING THE PANDEMIC BASED ON PROBLEM-BASED LEARNING
}

\author{
Devi Ayu Septiani ${ }^{1}$, A. A. Ayu Trisna Handayani ${ }^{1 *}$, Hermansyah ${ }^{1}$, Abdul Syukur $^{2}$, Jamaluddin $^{2}$ \\ ${ }^{1}$ Magister of Science Education, University of Mataram, Indonesia \\ ${ }^{2}$ Biology Education Study Program FTTE University of Mataram, Mataram, Indonesia \\ *Email: ayutrisna1206@gmail.com
}

Acceped: August 06 2021. Approved: Sept 01 2021. Published: Sept 042021

\begin{abstract}
Chemistry e-modules based on Problem-Based Learning $(P B L)$ are teaching materials based on electronic learning models or e-learning as a solution during the Covid-19 pandemic for students to learn independently. The purpose of this study is to assess PBL-based academic e-modules from the aspect of validity and feasibility in achieving its learning objectives. The approach used is development research according to the Thiagarajan model. The results showed that at the define stage, an analysis was conducted on the Curriculum 13 (K13) module of the Ministry of Education and Culture (Kemendikbud) with the material "chemical bonding" of Grade $\mathrm{X}$ at SMAN 3 Lembar. Furthermore, a module designed using an electronic display integrated with the PBL model was done at the design stage. Meanwhile, the expert validation result obtained an average of 0.86 , categorized as valid and feasible criteria at the development stage. The result of students' responses obtained $72.73 \%$ (good criteria), and the result of the chemistry teachers' responses obtained $88.06 \%$ (very good criteria). The PBL-based Chemistry e-module on chemical bonding material is feasible as a Chemistry learning solution for Class X of SMAN 3 Lembar.
\end{abstract}

Keywords: e-module, Problem Based Learning (PBL), chemical bonding, Covid-19 Pandemic

\section{INTRODUCTION}

The Industrial Revolution 4.0 has fundamentally resulted in changes in the way humans think, from conventional to digital [1-3]. Changes in the Industrial Era 4.0 require the world of education to innovate learning by integrating it with technology and information [4-5]. Thus, optimal use of multimedia can positively impact learning processes and outcomes [7-8].

The use of multimedia in Chemistry learning is a means of displaying chemistry's characteristics, such as macroscopic, submicroscopic, and symbolic, by combining multimedia elements [9]. Regarding the diversity of learning media as technological products, electronic modules or e-modules provide convenience for users to obtain learning materials through access to smartphones, tablets, and laptops [10].

The learning module is designed as a source of independent learning for students. The electronic design module has the aim that learning is not teacher-centered but student-centered. In this case, learning using e-modules can increase students' motivation and interest in learning [11-13]. Modules in the learning process can facilitate students in learning independently and face-to-face [14-15].

Electronic modules have relevance to learning that prioritizes problem-solving or Problem-Based Learning (PBL). In PBL learning, students form small groups and present open-ended problems to solve and answer questions [16-17]. The PBL method is designed to activate and construct prior knowledge. It is related to real- world learning, where the teacher functions as a facilitator for students to develop their knowledge base [18]. According to Botty \& Shahrill, ProblemBased Learning is learning-oriented towards providing problems to achieve the desired learning objectives [19]. Giving problems as an orientation to learning is a simulation for students in dealing with everyday problems so that they are encouraged to learn independently.

Problem-Based Learning, according to Mariani et al., is as follows: (1) giving problemoriented tasks to students, (2) organizing students to conduct research, (3) assisting individual and group investigations, (4) presenting the results of discussions, and (5) evaluate the results of the solution [20]. According to Wood, the purpose of PBL learning is that students can use problems in everyday life as triggers to achieve learning goals. Thus, the problem is not only solved but can also be used to improve student understanding [21]. In general, PBL involves the main question or problem posed by the teacher, which then students work together and decide the appropriate strategy to solve the problem [22-23].

PBL-based electronic modules can help students improve problem-solving skills, critical thinking skills, and intellectual skills [24]. In addition, the use of PBL-based e-modules can improve science processing skills [25]. PBL-based e-modules can improve concept mastery and help students learn independently [26]. Learning using PBL-based e-modules can help students express, argue, solve, or discuss problems in learning [27].

Chemistry learning requires learning innovations through PBL-based electronic 
modules. However, the design of Chemistry learning during the Covid-19 Pandemic has not yet developed many electronic-based learning integrated with the PBL model, especially high schools such as SMAN 3 Lembar where information technology has not yet become a necessity in the learning process. Meanwhile, during the Covid-19 Pandemic, electronic-based learning is a solution to overcome the limited faceto-face time at school. Therefore, This study aims to determine the feasibility of a PBL-based emodule that can be used as an alternative to distance learning during the pandemic.

\section{RESEARCH METHOD}

This research is conducted at SMAN 3 Lembar in May 2021. The population in this study are all students of Class X of Science Department of SMAN 3 Lembar with a total population of 22 people. The sampling technique used is the saturated sampling technique. Saturated sampling is a sampling technique using all members of the population. It is because the population is relatively small, with less than 30 people. Thus, the sample in this study is all students registered as Class $\mathrm{X}$ students of the Science Department of SMAN 3 Lembar, totaling 22 people.

The variable in this study is the PBL-based Chemistry e-module innovation on chemical bonding material for Class $\mathrm{X}$ of the Science Department. The approach used was the development research approach. The steps of development research in this study follow Thiagarajan et al., i.e., the 4D Model consisted of stages: define, design, develop, and disseminate [28].

In the define stage, a preliminary-to-final analysis and material analysis of the PBL-based Chemistry e-module on chemical bonding materials is conducted. Analysis of the material is carried out through library research activities on the books and modules used by SMAN 3 Lembar. The analysis results are used as a reference in the preparation of the e-module content framework, which describes the overall content of the material included in the emodule, complete with the learning flow and display design of the PBL-based Chemistry emodule teaching material.

In the "design" stage, the initial preparation of the e-module format is carried out with the help of Microsoft Word. After that, the file is converted to pdf format. Furthermore, the pdf module is turned into an interactive e-module with the help of Flip PDF Professional software. The function of the software is to convert the initial format of the module in pdf format into electronic form with videos, moving animations, pop-up images, and interactive practice questions. The output of Flip PDF Professional software can be accessed online (in $\mathrm{html}$ form) or offline (in exe form). Here is the online access

link

of

https://online.flipbuilder.com/wndty/cimj/.

After compiling materials and making PBLbased Chemistry e-modules, the "develop" stage is conducted, i.e., a feasibility test with expert validation tests and limited trials. The expert validation test in this study is conducted with the help of 3 material-expert lecturers to determine the suitability of the PBL-based emodule content developed with the expected goals and make improvements to the products that have been developed. After the examiner states that the media is feasible to use, then the learning media can be predicated as "valid," and the limited trial is then conducted. In this study, a limited test is conducted on the responses of 22 students of Class X SMAN 3 Lembar and 16 Chemistry teachers. Furthermore, the fourth stage in this study (disseminate) is a broad test. However, this research is limited to the "develop" stage, which is to produce a product in the form of a PBL-based Chemistry e-module.

Aiken's $\mathrm{V}$ analysis is used to test the validity of the product, and then the results are consulted and displayed in the Aiken Index Range Category Table according to Retnawati [34].

The practicality of the resulting product is tested using a questionnaire response of students and Chemistry teachers. Furthermore, the percentage of student responses is converted with the following criteria (Table 1) [31].

Table 1. Responses Criteria

\begin{tabular}{ccc}
\hline No. & Value & Criteria \\
\hline 1 & $80 \%<\mathrm{x} \leq 100 \%$ & very good \\
2 & $60 \%<\mathrm{x} \leq 80 \%$ & good \\
3 & $40 \%<\mathrm{x} \leq 60 \%$ & fair good \\
4 & $20 \%<\mathrm{x} \leq 40 \%$ & less good \\
5 & $0 \%<\mathrm{x} \leq 20 \%$ & not good \\
\hline
\end{tabular}

\section{RESULTS AND DISCUSSION \\ Results of "Define" Stage}

The "define" stage defines and identifies the stages in determining the subject matter, objectives, and scope to be investigated in the developed product. The "define" stage consists of problem analysis (beginning-late), student analysis, task analysis, concept/material analysis, and specification of learning objectives. Problem analysis is carried out at SMAN 3 Lembar located on the Persada Lendang Garuda highway, East Mareje Village, Sheet District, West Lombok Regency. The problem analysis aims to analyze and determine the basic problems faced by SMAN 3 Sheets in learning chemistry so that PBL-based Chemistry e-module innovation is needed. The results of interviews and observations with teachers stated that the curriculum used at SMAN 3 Lembar is the 2013 Curriculum (K13) and used teaching materials in the form of the K13 module from the Ministry of Education and Culture. In addition, lecture, question-and-answer, and demonstration (practicum) learning methods are applied in the 
learning process. The observation results show that learning during the pandemic makes it quite difficult for students to understand the learning module without teacher guidance. Furthermore, for the analysis of students, it is conducted by interviews and observations. It is found that students' abilities are different in receiving and responding to the subject matter and affecting the interest and enthusiasm of students in the learning process. In concept analysis, task analysis, and classification of learning objectives, it is found that an analysis of the chemical bond learning material is conducted with three sub-topics: (1) ionic bonds, (2) covalent bonds, and (3) metal bonds. In the specification of learning objectives, an analysis of core competencies and basic competencies is conducted. The selected basic competencies are
KD 3.9 and 4.9, which are chemical bonding materials.

\section{Results of "Design" Stage}

The design stage aims to determine the selection of suitable media for the purpose, format selection, and initial design. The media used to provide subject matter are e-modules that can be accessed offline and online using electronics (smartphones or laptops). The format of the electronic module (e-module) is developed according to the needs of the analysis at the "define" stage. Thus, for the design of the developed e-module, the modified Prastowo format is used [29]. The format for the developed electronic module (e-module) are as follows.

Table 2. Outline of PBL-based Electronic modules

\begin{tabular}{lcc}
\hline \multicolumn{1}{c}{$\begin{array}{c}\text { Beginning } \\
\text { Section }\end{array}$} & Content Section & Final Section \\
\hline Cover & Material Title & Evaluation \\
Introduction & Phase 1 & Answer key \\
Table of Contents & Phase 2 & Bibliography \\
Glossary & Phase 3 & \\
Concept maps & Phase 4 & \\
Module Identity & Phase 5 & \\
Basic Competencies & & \\
Brief Description of Material & & \\
Module Instruction Manual & & \\
Introductory Material & & \\
\hline
\end{tabular}

The resulted e-module design is referred to as the initial product. The cover design can be seen in Figure 1.

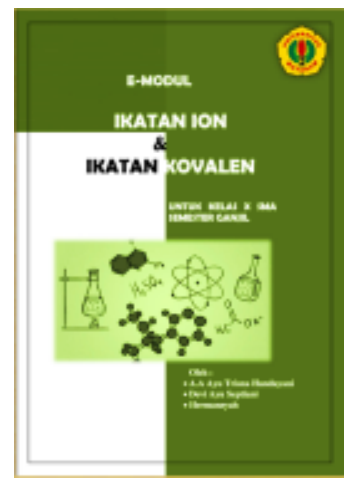

Figure 1. Design of E-Module Cover

The content section of the e-module consists of a description of the material according to the stages of the PBL learning model and practice questions that are packaged in such a way with the help of animated video displays and images so that students are more active in learning (Figure 2). The final section of the e-module consists of an evaluation and a bibliography (Figure 3 ).

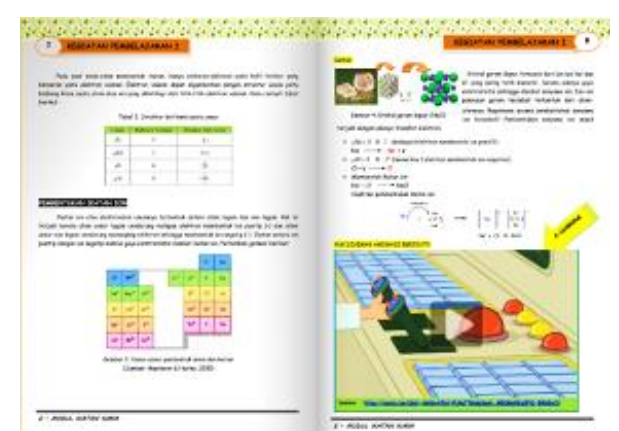

Figure 2. Design of E-Module Content Section

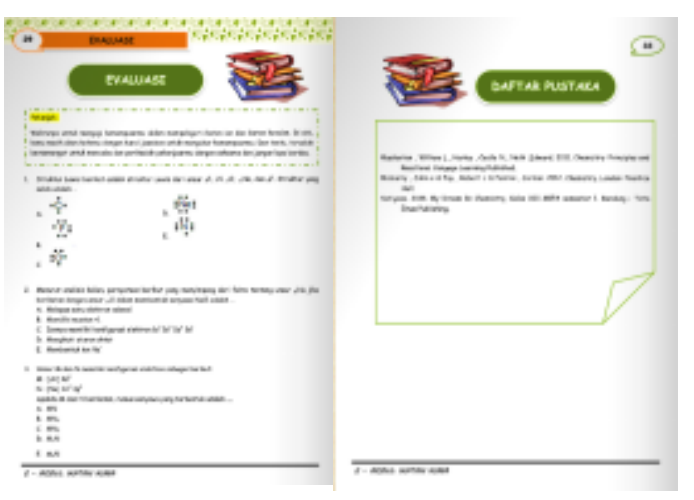

Figure 3. Design E-Module Final Section 


\section{Results of "Develop" Stage}

The "develop" stage in this study consists of expert validation and limited testing of the product. The product result is in the form of PBL-based Chemical e-modules on chemical bonding materials, which can be accessed at https://online.flipbuilder.com/wndty/cimj/ has been adapted to the modules used in SMAN 3 Lembar, the module from the Ministry of Education and Culture 2013 Curriculum.

In this study, a validation test has been conducted by experts on the developed e-module. Expert validation is by presenting experienced experts in the field of chemistry learning, i.e., 3 expert lecturers, to assess the content of the emodule. The analysis used for the validity test is the Aiken V index, which is to determine the level of validity of the developed PBL-based Chemical e-module. The results of the expert's assessment of the feasibility of the material can be seen in Table 3.

Table 3. Experts Validation Results

\begin{tabular}{lcc}
\hline \multicolumn{1}{c}{ Aspects } & Value & Category \\
\hline Cover feasibility & 0,92 & Very valid \\
Materials & 0,78 & valid \\
feasibility & & \\
Language & 0,87 & Very valid \\
Graphics & 0,86 & Very valid \\
\hline \multicolumn{1}{c}{ Overall Average } & 0,86 & Very valid \\
\hline
\end{tabular}

Data analysis from material experts obtained an average result of 0.86 . Based on the criteria set, it can be explained that the e-module is in the very valid criteria and is suitable to use in the learning process. The expert validation results show that the PBL-based Chemistry e-module developed has good content/material feasibility, easy-tounderstand language, and attractive e-module display, and is very helpful for students to understand learning materials independently and optimize their skills [30].

PBL-based Chemical e-modules that have been valid are then tested with limited trials using response analysis. This test was conducted on students of Class $\mathrm{X}$ of Science Department at SMAN 3 Lembar and Chemistry teachers. Analysis of student responses consists of 6 aspects: ease of understanding, independent learning, active learning, interest, presentation, and aspects of use. The feasibility of the developed e-module can be seen from the students' responses and the chemistry teachers. The results of the analysis of student responses are presented in graphical form (Figure 4).

The graph in Figure 4 shows the different percentages. The highest percentage is obtained in use, which is $78.64 \%$ in the good category. Meanwhile, the lowest percentage is in learning activity which is $60 \%$ or good fair category. This aspect of the activity is related to the students' interest in working on the exercises contained in the e-module. The average calculation for the student responses shows a percentage of $72.73 \%$ and belongs to the good category [31]. It shows a positive response on the PBL-based Chemical emodules on chemical bonding materials, which is easy to learn, has an interesting content display and can be used independently. It is support for chemistry learning both outside and inside the classroom.

The analysis of chemistry teacher's response uses 18 statements. Here are the results of the chemistry teacher response data analysis presented in tabular form in Table 4.

\section{Result of the Students Responses}

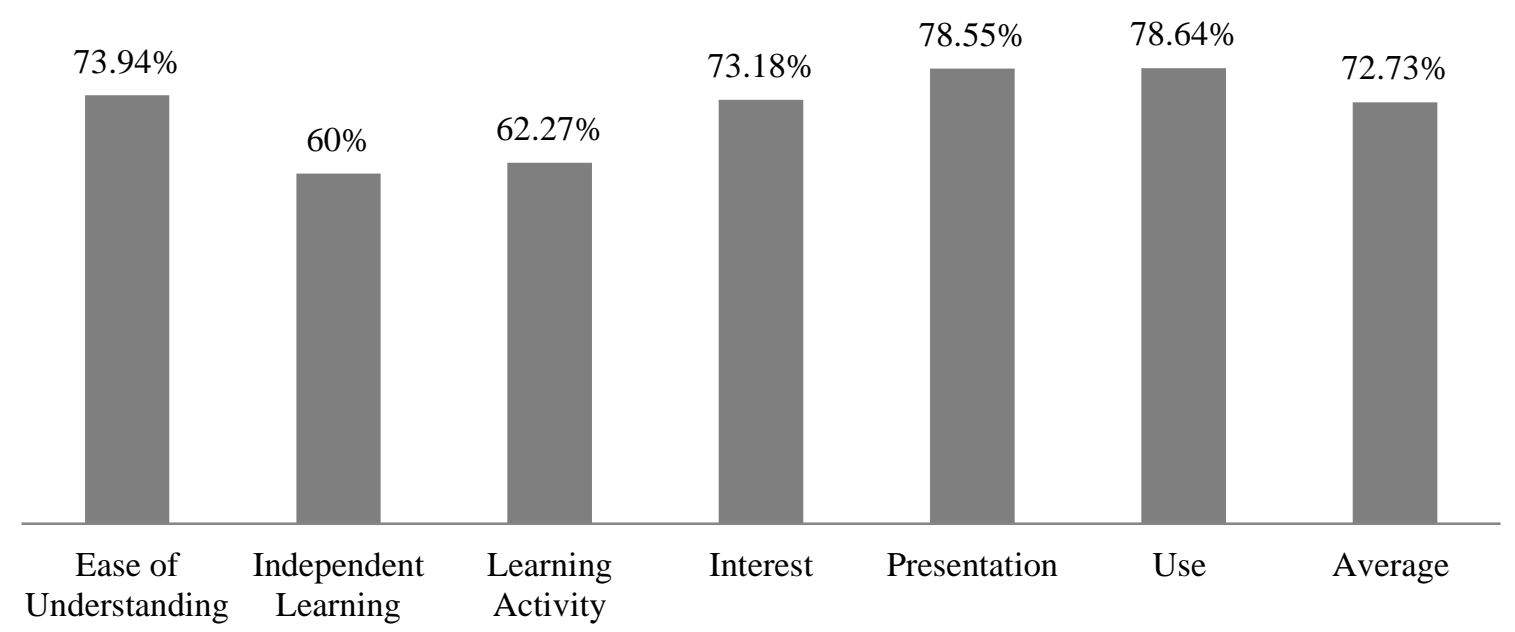

Figure 4. Graph of Student Response Results 
Table 4. Results of Chemistry teachers' responses

\begin{tabular}{|c|c|}
\hline Statements & Percentages \\
\hline Learning objectives are clearly explained. & $92,50 \%$ \\
\hline The learning objectives are in accordance with the Basic Competencies. & $88,75 \%$ \\
\hline There is a relevance between the objectives and the material. & $90 \%$ \\
\hline The material in the learning media is given systematically. & $87,50 \%$ \\
\hline The material in the learning media is easy to follow. & $90 \%$ \\
\hline The content of the material is in accordance with the learning objectives. & $90 \%$ \\
\hline The material presented is in accordance with scientific truth. & $87,50 \%$ \\
\hline The material presented is according to the latest developments & $86,25 \%$ \\
\hline The material presented is in accordance with everyday life. & $90 \%$ \\
\hline The use of video is in accordance with the learning objectives. & $87,50 \%$ \\
\hline The use of practice questions is in accordance with the learning objectives. & $87,50 \%$ \\
\hline The suitability between the level of difficulty with the cognitive development of students. & $82,50 \%$ \\
\hline The language used is good. & $90 \%$ \\
\hline The language used is easy to understand. & $90 \%$ \\
\hline The style of language used is communicative. & $87,50 \%$ \\
\hline The language style used is suitable for students. & $85 \%$ \\
\hline Language used in learning media is quite clear. & $86,25 \%$ \\
\hline The language error rate in the learning media is small. & $86,25 \%$ \\
\hline Total & $88,06 \%$ \\
\hline
\end{tabular}

The result in Table 4 above shows different percentages obtained. The highest percentage of the responses is the statement of learning objectives clearly explained, i.e., $92.50 \%$, and is included in the very good response category [31]. While, the lowest percentage of the responses is the statement of suitability between the level of difficulty with the cognitive development of students, namely $82.50 \%$, and included in the category of very good response. Meanwhile, the analysis of the average calculation for the chemistry teacher response shows a percentage of $88.06 \%$ and is included in the very good category. The percentage shows that the PBL-based chemical E-module on the developed chemical bonding material positively responded to the developed product.

The process of developing a PBL-based Chemical e-module in this study uses this emodule. The steps of development research in this study are by Thiagarajan et al, the 4D model, consisting of the stages of define, design, develop, and disseminate [28]. However, these e-module development stages are limited to the developing stage, which is to produce a product in the form of a PBL-based Chemical e-module. In its development, this product is based on data from observations and interviews, including needs analysis and relevant research results used as a theoretical basis.

The development of this PBL-based Chemistry e-module involves using several performance application programs and software such as Flip PDF Professional, Microsoft Office, and Portable Document Format (PDF). The output of this e-module product is in the form of online access links and digital book files with an exe file extension that can be accessed offline. In addition, the PBL-based Chemical e-module development product passed several stages of testing to see the feasibility of the product. Validation tests by experts and limited trials on students of SMAN 3 Lembar and several chemistry teachers. With the PBL-based Chemistry e-module developed by researchers, the use of paper in learning can be reduced. Moreover, its use is practical and easy without being limited by place and time because it can be accessed anywhere and anytime using media access such as smartphones, tablets, and laptops owned by students. In addition, the e-module developed uses a language that is adapted to the abilities of students so that the limitations of teaching materials by teachers in the Chemistry learning process can be helped [10]-[32]-[33].

\section{CONCLUSION}

The acquisition of a feasibility test in the form of questionnaires and statements by the expert was in an average value of 0.86 (very valid and feasible). Meanwhile, the results of the analysis of the PBL-based Chemistry e-module on chemical bonding materials according to SMAN 3 Lembar, students gave a good response, and the chemistry 
teachers responded very well. It is following the calculation of the average percentage of each questionnaire which is $72 \%, 73 \%$, and $88.06 \%$.

\section{THANK-YOU NOTE}

Thank you to the Magister of Science Education Study Program at the University of Mataram through the Independent Study course, SMAN 3 Lembar, and other parties who have contributed significantly to this research.

\section{REFERENCES}

[1] Zubaidah, S. (2018). Mengenal 4C: Learning and innovation skills untuk menghadapi era revolusi industri 4.0. In 2 nd Science Education National Conference (Vol. 13). https://www.researchgate.net/profile/SitiZubaidah-7/publication/332469989

[2] Tjandrawinata, R. R. (2016). Industri 4.0: Revolusi industri abad ini dan pengaruhnya pada bidang kesehatan dan bioteknologi. Jurnal Medicinus, 29(1), 31-39. https://www.researchgate.net/publication/293 $\underline{695551}$

[3] Schwab, K. (2018). The global competitiveness report 2018. In World Economic Forum (Vol. 671).

[4] Karlina, D. M., Andi, U. T. P., Khairil, W. A \& Abdullah. (2021). Efektivitas Modul Elektronik Berbasis Web Dipadu Problem Based Learning Terhadap Motivasi Belajar pada Materi Pencemaran Lingkungan. Jurnal Pendidikan Sains Indonesia, 9(1): 139-150. https://doi.org/10.24815/jpsi.v9i1.18135

[5] Ghavifekr, S., \& Rosdy, W. A. W. (2015). Teaching and learning with technology: Effectiveness of ICT integration in schools. International Journal of Research in Education and Science, 1(2), 175-191. https://files.eric.ed.gov/fulltext/EJ1105224.pd $\underline{\mathrm{f}}$

[6] KAREEM, A. A. (2018). The use of multimedia in teaching biology and Its Impact on students' learning outcomes. The Eurasia Proceedings of Educational and Social Sciences, 9, 157-165. https://dergipark.org.tr/en/pub/epess/issue/389 $\underline{00 / 457937}$

[7] Aloraini, S. (2012). The Impact of Using Multimedia on Students' Academic Achievement in the College of Education at King Saud University.Journal of King Saud University Languages and Translation,24(2): 75-82.

https://doi.org/10.1016/j.jksult.2012.05.002.

[8] Zhang, F. (2012). Significances of Multimedia Technologies Training. Physics Procedia,33,2005-2010. https://doi.org/10.1016/j.phpro.2012.05.315
[9] Mashami, R. A., \& Khaeruman, K. (2020). Pengembangan Multimedia Interaktif Kimia Berbasis PBL (Problem Based Learning) untuk Meningkatkan Keterampilan Generik Sains Siswa. Hydrogen: Jurnal Kependidikan Kimia, 8(2), 85-96. https://doi.org/10.33394/hjkk.v8i2.3138

[10] Trilestari, K., \& Almunawaroh, N. F. EModule as a Solution for Young Learners to Study at Home. In 4th Sriwijaya University Learning and Education International Conference (SULE-IC 2020) (pp. 364-369). Atlantis Press. https://doi.org/10.2991/assehr.k.201230.132

[11] Michau, F., Gentil, S., \& Barrault, M. 2001. Expexted benefits of web-based learning for engineering education: examples in control engineering. European Journal of Engineering Education, 26:151-168. https://doi.org/10.1080/03043790110034410

[12] Husna, N. H., Syafmen, W., \& Winarni, S. (2020). Desain E-Modul Berbasis Problem Based Learning Dengan Berbantuan Maple Untuk Meningkatkan Minat Belajar Siswa Pada Materi Sistem Persamaan Linear Tiga Variabel (Doctoral dissertation, Universitas Jambi).

[13] Harefa, N., \& Fransisca, D. S. N. (2020). Improvement of student's learning outcomes and motivation with chemical practicum emodule. Jurnal Pendidikan Kimia, 12(1), 1019. https://doi.org/10.24114/jpkim.v12i1.17708

[14] Rahayu, J., \& Solihatin, E. (2019). Pengembangan Modul Pembelajaran Online Pada Mata Pelajaran Kimia. Jurnal Ilmiah Wahana Pendidikan, 5(1), 13-28. https://jurnal.unibrah.ac.id/index.php/JIWP/ar ticle/view/71

[15] Nugroho, Y. S., Daryanto, D., Achmad, F., Ningrum, L. E. C., \& Rohman, M. (2019). Pengembangan Modul Pembelajaran Mata Kuliah Energi Alternatif Program Studi Pendidikan Vokasional Teknik Elektro. JINop (Jurnal Inovasi Pembelajaran), 5(1), 93-106.

[16] Ali, S. S. (2019). Problem Based Learning: A Student-Centered Approach. English language teaching, 12(5), 73-78. https://doi.org/10.5539/elt.v12n5p73

[17] Crowley, B. M. (2015). The effects of problem-based learning on mathematics achievement of elementary students across time.

https://digitalcommons.wku.edu/cgi/viewcont ent.cgi? article $=2449 \&$ context $=$ theses

[18] Schmidt, H. G., Rotgans, J. I., \& Yew, E. H. (2011). The Process Of Problem-Based Learning: What Works and Why. Medical education, $\quad$ 45(8), 792-806. 
https://doi.org/10.1111/j.1365-

2923.2011.04035.x

[19] Botty, H. M. R. H., Shahrill, M., Jaidin, J. H., Li, H. C., \& Chong, M. S. F. (2016). The implementation of problem-based learning (PBL) in a year 9 mathematics classroom: A study in Brunei Darussalam. International Research in Education, 4(2), 34-47. http://www.macrothink.org/journal/index.php/ ire/article/view/9466

[20] Mariani, S. W., \& Kusumawardani, E. D. (2014). The Effectiveness of Learning by PBL Assisted Mathematics Pop Up Book Againts The Spatial Ability in Grade VIII on Geometry Subject Matter. Internasional Journal of Education and Research, 2(2), 531-548.

[21] Wood, D. F. (2003). Problem Based Learning. BMJ, $326(7384): \quad 328-\quad 330$. https://doi.org/10.1136/bmj.326.7384.328

[22] Chin, C., \& Chia, L. G. (2004). Problembased learning: Using students' questions to drive knowledge construction. Science education, $88(5)$, 707-727. https://doi.org/10.1002/sce.10144

[23] Gorghiu, G., Drăghicescu, L. M., Cristea, S., Petrescu, A., \& Gorghiu, L.M. (2015). Problembased Learning - An Efficient Learning Strategy in the Science Lessons Contex. Procedia - Social and Behavioral Sciences, $\quad 191$ 1865-1870. https://doi.org/10.1016/j.sbspro.2015.04.570

[24] Hafsah, N. R. j., Rohendi, D., \& Purnawan. 2016. Penerapam media pembelajaran modul elektronik untu meningkatkan hasil belajar peserta didik pada mata pelajaran teknologi mekanik. Journal of Mechanic al Engineering Education, 3(1):106-112. : https://doi.org/10.17509/jmee.v3i1.3200

[25] Mulyar, L. D., Serevina, V., \& Budi, A. S. (2018, November). Pengembangan Modul Elektronik Model Discovery Learning Materi Hukum Newton Tentang Gerak Dengan Video Stop Motion. In Prosiding Seminar Nasional Fisika (E-Journal) (Vol. 7, pp. SNF2018-PE).

https://doi.org/10.21009/03.SNF2018.01.PE.1 7

[26] Sari, Y. P., Sunaryo, Serena, V., \& Astra, I. M. 2019. Developing e-module for fluids based on problem - based learning (PBL) for senior high school students. Journal of Physics: Conference Series, 1185(1):1-8. https://iopscience.iop.org/article/10.1088/174 2-6596/1185/1/012052/meta

[27] Pada, A. U. T., Khairil, K., Artika, W., \& Abdullah, A. (2021). Efektivitas Modul Elektronik Berbasis Web Dipadu Problem
Based Learning Terhadap Motivasi Belajar pada Materi Pencemaran Lingkungan. Jurnal Pendidikan Sains Indonesia (Indonesian Journal of Science Education), 9(1), 139-150. https://doi.org/10.24815/jpsi.v9i1.18135

[28] Thiagarajan, Sivasailam, dkk. (1974). Instructional Development for Training Teachers of Exceptional Children. Washinton DC: National Center for Improvement Educational System

[29] Prastowo, A. (2011). Metode penelitian kualitatif dalam perspektif rancangan penelitian. Jogjakarta: Ar-Ruzz Media.

[30] Irman, S., \& Waskito, W. (2020). Validasi Modul Berbasis Project Based Learning pada Mata Pelajaran Simulasi dan Komunikasi Digital. Jurnal Ilmiah Pendidikan dan Pembelajaran, $\quad 4(2), \quad$ 260-269. http://dx.doi.org/10.23887/jipp.v4i2.26156

[31] Zakirman dan Hidayati. 2017. "Praktikalitas Media Video dan Animasi dalam Pembelajaran Fisika Di SMP”. Jurnal Ilmiah Pendidikan Fisika Al-BiRuNi. 6 (1): 85-93

[32] Laili, I., Ganefri, G., \& Usmeldi, U. (2019). Efektivitas Pengembangan E-Modul Project Based Learning pada Mata Pelajaran Instalasi. Jurnal Imiah Pendidikan dan Pembelajaran, 3(3), 306-315. https://ejournal.undiksha.ac.id/index.php/JIPP /article/download/21840/13513

[33] Sadikin, A., \& Hamidah, A. (2020). Pembelajaran Daring di Tengah Wabah Covid-19:(Online Learning in the Middle of the Covid-19 Pandemic). Biodik, 6(2), 214224. https://doi.org/10.22437/bio.v6i2 